\title{
Production of Hydroponic Lettuce under Different Salt Levels of Nutritive Solution
}

\author{
Rafaela Felix Basilio Guimarães ${ }^{1}$, Ronaldo do Nascimento ${ }^{1}$, Daniele Ferreira de Melo ${ }^{1}$, Jailton Garcia Ramos ${ }^{1}$, \\ Mariana de Oliveira Pereira ${ }^{1}$, José Alberto Ferreira Cardoso $^{2} \&$ Sabrina Cordeiro de Lima ${ }^{1}$ \\ ${ }^{1}$ Universidade Federal de Campina Grande, Brazil \\ ${ }^{2}$ Instituto Federal do Tocantins, Brazil \\ Correspondence: Rafaela Felix Basilio Guimarães, Universidade Federal de Campina Grande, Brazil. E-mail: \\ rafaellafelix_@hotmail.com
}

Received: July 30, 2017

Accepted: September 21, 2017 Online Published: October 15, 2017

doi:10.5539/jas.v9n11p242

URL: https://doi.org/10.5539/jas.v9n11p242

\begin{abstract}
The objective of this study was to evaluate the effects of different levels of salinity on the production of two cultivars of crisp lettuce under hydroponic cultivation. The research was performed in a protected environment at the Federal University of Campina Grande (UFCG), state of Paraíba, during in the period from 1 to 22 September 2016. The experimental design was completely randomized (CRD) which involved $4 \times 2$ factorial scheme with four levels of electrical conductivity of the nutrient solution $\left(1.6,3.6,5.6\right.$ and $\left.7.6 \mathrm{dS} \mathrm{m}^{-1}\right)$ and two lettuce cultivars, Valentina $(\mathrm{C} 1)$ and Alcione $(\mathrm{C} 2)$, that totalized 8 treatments with 3 replicates. The evaluated variables were fresh and dry biomass of leaves, stems and roots. The results were subjected to analysis of variance by F-test $(p<0.05)$, the averages were compared by Tukey's test $(p<0.01$ and $p<0.05)$, and quantitative variables data were submitted to regression test. It was observed that the fresh leaves biomass and fresh stem biomass were significantly affected by salinity in all evaluated periods. However, cultivar factor singly presented significant statistical difference only for fresh root biomass. There was statistical interaction between the factors at 15 DAT for dry leaves biomass and at 21 DAT for dry stem biomass. It was concluded that, although some variables were significantly affected by the salinity of the nutritive solution, the hydroponic lettuce production was satisfactory in NFT system for electrical conductivity up to $3.5 \mathrm{dS} \mathrm{m}^{-1}$ for variables with commercial relevance.
\end{abstract}

Keywords: salinity, vegetables, Lactuca sativa L.

\section{Introduction}

The Brazilian semi-arid region presents similar edafoclimatic characteristics to other semi-arid regions of the world, periodic droughts, shallow, sandy, saline and nutrient poor soils essential to the development of plants, average temperatures between 23 and $27{ }^{\circ} \mathrm{C}$, low rainfall, and is still mostly located on about basement crystalline, which tends to cause salinization of groundwater (Rebouças, 1997), as shown in the study of Andrade Junior et al. (2006), where it states that wells that exploit stored water in fractures of the crystalline may have electrical conductivity above $15 \mathrm{dS} \mathrm{m}^{-1}$. Therefore, it is necessary, according to Andrade et al. (2012), the adoption of irrigation so that crops exploited achieve adequate development and economically competitive productivities. Fageria (1989) emphasizes the importance of using tolerant crops to salinity, as one of the solutions for the reincorporation from salinized areas to the productive scenario, considering that the use of salinized water can can cause morphological, structural and metabolic changes in plants, compromising growth, reducing the crop cycle and its productivity (Silva et al., 2010).

Given this perspective, studies on the problem have been developed with the objective of making feasible the use of salinized waters as an input for hydroponic cultivation. In this case, the main vegetable that has been focus of research is lettuce (Paulus et al., 2010; Santos et al., 2010; Alves et al., 2011; Maciel, 2012).

According to Paulus et al. (2010), lettuce (Lactuca sativa L.) is the most produced crop in hydroponic system in Brazil through the nutrient film technique (NFT). In this system, the soil or substrate is replaced by a nutrient solution that provides all the essential nutrients for plant development. 
In studies carried out with hydroponic lettuce using salinized nutrient solution, Soares (2007) found that in the NFT system there was a greater tolerance to salinized in relation to planting in the soil, because in this type of cultivation the matric potential is zero, establishing a greater total potential of available water which facilitate the absorption of water by the plants.

Oliveira et al. (2011) evaluating the performance of lettuce cultivars submitted to salinity, observed a reduction in the development of the plants with the increase of water salinity, but it points out that the level of response varied among the studied cultivars.

The objective of this work was to evaluate the effect of different levels of salinity of the nutrient solution on the accumulation of biomass of two cultivars of crispy lettuce under hydroponic cultivation.

\section{Material and Methods}

The experiments was performed in during in the period from 01 to 22 September 2016 in a greenhouse located in Campus I at Federal University of Campina Grande (UFCG), Campina Grande city ( $7^{\circ} 13^{\prime} 50^{\prime \prime}$ S, 35 $52^{\prime} 52^{\prime \prime}$ W, $551 \mathrm{~m}$ asl.), state of Paraíba, Brazil.

The greenhouse with dimensions of $6.0 \mathrm{~m}$ wide $\times 10.0 \mathrm{~m}$ in length and $3.0 \mathrm{~m}$ high, was a metallic structure, of the arch cover type, which was covered with low density $150 \mu \mathrm{m}$ polyethylene, with the sides being covered with a shading screen having $80 \%$ index protection. Inside the greenhouse it has four hydroponic planting stands in NFT system, spaced from each other in $0.80 \mathrm{~m}$, with initial height of $1.10 \mathrm{~m}$ and slope of $2 \%$. The profiles are spaced $0.10 \mathrm{~m}$ and have a length of $4.0 \mathrm{~m}$.

The profiles for each treatment were interconnected by means of auxiliary pipes to a rigid plastic tank with capacity of 300 liters, where the nutrient solution was stored. Twenty four cultivation profiles were used, arranged in four benches, the hoses responsible for the distribution of the solution in the profiles were randomly organized so that each hose was connected to the tank with the specific salinity level for each treatment.

The flow rate of the solution in the channels and the power of the pump was determined considering the recommendation of Furlani et al. (1999). Four simple centrifugal pumps were used, where each one was responsible for sucking and repression the nutrient solution for 6 profiles. Each pump was connected to an analog timer attached to the electric power to keep the solution circulating automatically. Timers were programmed for irrigations every 15 minutes during the day, and one-hour intervals at night.

The experimental design was the completely randomized design (CRD), where the factors studied were arranged in $4 \times 2$ factorial design, two cultivars of lettuce, Valentina (C1) and the Alcione (C2) submitted to four levels of electric conductivity of the nutritive solution $\left(\mathrm{EC}_{\mathrm{SN}}\right)\left(\mathrm{S} 1=1.6, \mathrm{~S} 2=3.6, \mathrm{~S} 3=5.6\right.$ and $\left.\mathrm{S} 4=7.6 \mathrm{ds} \mathrm{m}^{-1}\right)$, with 3 replicates (each replicates is represented by a profile) each tratament. The ECsn values were determined because the lettuce was considered, according to Ayers and Westcot (1999), moderately sensitive to salinity, presenting salinity of the saturation extract of $1.3 \mathrm{dS} \mathrm{m}^{-1}$. This limit makes the production of this crop in the Brazilian semi-arid region unfeasible, due to the regional characteristics previously mentioned, emphasizing in this way the importance of the levels chosen for research. In the formulation of the nutrient solution it was used the Hydrogood Fertwas compound, which contains all the necessary macronutrients and micronutrients required by plants, the calcium nitrate and the chelated iron. The preparation of the solution was performed according to the manufacturer's recommendations, which follow the methodology proposed by Furlani et al. (1999). The management of the solution followed the recommendation of the same author.

The compound, the calcium nitrate and the chelated iron were diluted separately to avoid the formation of insoluble compounds, posteriorly they were added to the final reservoir.

For the treatment $\mathrm{S} 1\left(1.6 \mathrm{dS} \mathrm{m}^{-1}\right)$, the solution was prepared with rainwater, due to the low salinity that it presents $\left(0.07 \mathrm{dS} \mathrm{m}^{-1}\right)$, considering that this treatment is the control and therefore, requires the lowest electrical conductivity of the nutrient solution (ECns), the treatments $\mathrm{S} 2\left(3.6 \mathrm{dS} \mathrm{m}^{-1}\right), \mathrm{S} 3\left(5.6 \mathrm{dS} \mathrm{m}^{-1}\right)$ and $\mathrm{S} 4\left(7.6 \mathrm{dS} \mathrm{m}^{-1}\right)$, due to the absence of destilled watter, were prepared with water from the local supply system of Campina Grande - PB, from Water and Sewage Company of Paraíba - CAGEPA, that presented it an electrical conductivity of $1.69 \mathrm{dS} \mathrm{m}^{-1}, \mathrm{In}$ this way, the amount of $\mathrm{NaCl}$ (sodium chloride) added to the solution to reach the values of ECns proposed in the research was smaller, compared to the use of distilled water.

The profiles were identified with each treatment and their respective replicates, where the transplanting of 12 lettuce seedlings spaced $0.25 \mathrm{~m}$ between plants was carried out. Two plants of each profile were left as edge, the first and the last, so that plants have the same level of competition for light and space for growth.

There was no need for chemical control of pests and diseases during the crop development. 
The variety used in the experiment was the crisp lettuce segment, Alcione and Valentina cultivars. The seedlings were purchased from producers in the region of Lagoa Seca - PB that produce hydroponic lettuce; they were produced in phenolic foam previously washed with running water, to eliminate possible residues from their manufacture, the foam was moistened inicially only with rain water, and posteriorly then with nutrient solution diluted to $50 \%$, using sub irrigation.

The seedlings were kept in a structure covered with a sombrite-type screen and then the seedlings obtained were transferred to development benches (nursery), and when they reached 6 to 8 final leaves (approximately 30 days), they were transported to Campus I of the UFCG, where the transplanting to final hydroponics was carried out.

There was daily monitoring of the solutions to ensure the correct electrical conductivity for each treatment, being verified through a Mca 150 benchtop conductivity meter, twice a day; when necessary, the same was adjusted by diluting the treatment with a nutrient solution of adjustment, previously prepared with rainwater and stored in an extra reservoir, as recommended by Furlani et al. (1999), or by the addition of $\mathrm{NaCl}$, when necessary, to concentrate the solution further.

Daily pH control was also performed through a model PH meter LUCA-210, to keep it between 5.5 and 6.5 (because it is the optimal range for nutrient absorption), adjusting it when necessary through a composed base solution by sodium hydroxide or an acid solution composed of sulfuric acid.

The maximum and minimum average air temperatures $\left(31.42^{\circ} \mathrm{C}\right.$ and $\left.19.29^{\circ} \mathrm{C}\right)$ and average relative air humidity $(62.66 \%)$ throughout the experimental period were measured using a digital hygrometer.

The variables of biomass accumulation were evaluated at 7, 14 and 21 days after transplanting (DAT). It was analyzed the fresh and dry biomass of leaves, stem and roots. The analyzes were destructive, where three plants were collected in each plot that refers to a composite experimental unit. To evaluate fresh biomass the plants were removed from the hydroponic planting system and there parts were separated in leaves, stem and roots and weighed utilizing a digital scale with $0.0001 \mathrm{~g}$ accuracy. After the parts were weighed, they were stored in paper bags, identified and placed under forced air circulation at $60^{\circ} \mathrm{C}$ until reaching constant weight. They were later removed and re-weighed separately to record the dry biomass.

The results were subjected to analysis of variance by F-test at $5 \%$ of probability $(\mathrm{p}<0.05)$; when significant, for qualitative variables the averages were compared by Tukey's test $(p<0.05)$. For quantitative variables data were submitted to regression test $(\mathrm{p}<0.05)$. In the analysis it was used the software SISVAR (Ferreira, 2014).

\section{Results and Discussions}

A variance analysis was performed on 7,14 and 21 days after transplanting (DAT), where results can be observed at Table 1. There was significant effect of salinity levels (SL) for fresh leaves biomass (FLB) and dry stem biomass (DSB) on the periods evaluated. The dry leaves biomass variable (DLB) showed significant difference at 14 DAT while the dry stem biomass (DSB) differed at 21 DAT for the salinity treatments aplied. The fresh root biomass (FRB) showed a statistically significant difference for SL only at 7 DAT and dry root biomass (DRB), in turn, was affected at the end of the cycle at 21 DAT. Comparing the cultivars (C) it was observed that there was no statistically significant difference for FLB and DRB over the research, however, for FRB the cultivars differed statistically throughout the cycle. FSB and DSB presented statistical difference only at 21 DAT and DLB differed statistically for the different treatments at 7 and 14 DAT. There was interaction effect $(\mathrm{SL} \times \mathrm{C})$ for FLB at $14 \mathrm{DAT}$ and DSB at $21 \mathrm{DAT}$. 
Table 1. Summary of the analysis of variance for fresh leaves biomass (FLB), dry leaves biomass (DLB), fresh stem biomass (FSB), dry stem biomass (DSB), fresh root biomass (FRB) and dry root biomass (DRB) variables at 7,14 and 21 DAT

\begin{tabular}{|c|c|c|c|c|c|c|c|}
\hline \multirow{2}{*}{ SV } & \multirow{2}{*}{ FD } & \multicolumn{6}{|c|}{ Average squares } \\
\hline & & FLB (g) & DLB (g) & FSB (g) & DSB (g) & FRB (g) & DRB (g) \\
\hline \multicolumn{8}{|c|}{ Period 1 (7 DAT) } \\
\hline SL & 3 & $479.59^{*}$ & $0.7951^{\mathrm{ns}}$ & $4.2933^{* *}$ & $0.0021^{\mathrm{ns}}$ & $46.19^{* *}$ & $0.1229^{\mathrm{ns}}$ \\
\hline $\mathrm{C}$ & 1 & $70.04^{\mathrm{ns}}$ & $0,0651 * *$ & $0.0051^{\mathrm{ns}}$ & $0.0007^{\mathrm{ns}}$ & $39.34^{* *}$ & $0.1232^{\mathrm{ns}}$ \\
\hline $\mathrm{SL} \times \mathrm{C}$ & 3 & $18.4861^{\mathrm{ns}}$ & $0.6451^{\mathrm{ns}}$ & $0,1826^{\mathrm{ns}}$ & $0.0037^{\mathrm{ns}}$ & $12.34^{\mathrm{ns}}$ & $0.0615^{\mathrm{ns}}$ \\
\hline Error & 14 & 127.66 & 0.2554 & 0.4799 & 0.0035 & 8.4177 & 0.0562 \\
\hline Total corrected & 23 & - & - & - & - & - & - \\
\hline $\mathrm{CV}(\%)$ & & 15.56 & 13.06 & 16.20 & 16.14 & 12.11 & 17.26 \\
\hline \multicolumn{8}{|c|}{ Period 2 (14 DAT) } \\
\hline SL & 3 & $6588.15^{* *}$ & $3.8797 * *$ & $74.4346^{* *}$ & $0.0671^{\mathrm{ns}}$ & $129.65^{\mathrm{ns}}$ & $0.1097^{\mathrm{ns}}$ \\
\hline $\mathrm{C}$ & 1 & $2101.69^{\mathrm{ns}}$ & $0.8288 * *$ & $14.3067^{\mathrm{ns}}$ & $0.0600^{\mathrm{ns}}$ & $551.61^{* *}$ & $0.2204^{\mathrm{ns}}$ \\
\hline $\mathrm{SL} \times \mathrm{C}$ & 3 & $1133.58^{\mathrm{ns}}$ & $1.0118^{* *}$ & $0.0892^{\mathrm{ns}}$ & $0.0328^{\mathrm{ns}}$ & $46.43^{\mathrm{ns}}$ & $0.0705^{\mathrm{ns}}$ \\
\hline Error & 14 & 1189.29 & 0.0615 & 90.335 & 0.0284 & 45.13 & 0.1868 \\
\hline Total corrected & 23 & - & - & - & - & - & - \\
\hline $\mathrm{CV}(\%)$ & & 16.66 & 2.59 & 22.69 & 25.72 & 13.57 & 21.19 \\
\hline \multicolumn{8}{|c|}{ Period $3(21 D A T)$} \\
\hline SL & 3 & $23088.29 *$ & $159.49 * *$ & $718.87 * *$ & $0.7586^{* *}$ & $56.27^{\mathrm{ns}}$ & $1.2454 *$ \\
\hline $\mathrm{C}$ & 1 & $2725.76^{\mathrm{ns}}$ & $83.88^{\mathrm{ns}}$ & $653.33^{* *}$ & $3.1682 * *$ & $909.58 * *$ & $0.0400^{\mathrm{ns}}$ \\
\hline $\mathrm{SL} \times \mathrm{C}$ & 3 & $4360.87^{\mathrm{ns}}$ & $40.28^{\mathrm{ns}}$ & $133.01^{\mathrm{ns}}$ & $0.2692 * *$ & $2.0985^{\mathrm{ns}}$ & $0.0946^{\mathrm{ns}}$ \\
\hline Error & 14 & 7103.66 & 35.69 & 97.30 & 0.0555 & 87.1732 & 0.3159 \\
\hline Total corrected & 23 & - & - & - & - & - & - \\
\hline $\mathrm{CV}(\%)$ & & 22.29 & 28.81 & 31.55 & 13.29 & 12.24 & 17.15 \\
\hline
\end{tabular}

Note. SV: Source of variation; FD: Freedom degree; SL: Salinity levels; C: cultivars; DAT: days after transplanting; CV: coeficiente of variation. * and **: Significant at $5 \%$ and $1 \%$ probability levels, respectively, by the F-test.

\subsection{Biomass of Leaves}

Regarding the fresh leaves biomass (FLB) of lettuce, there was a significant effect of salt level (SL) to the 7, 14 and 21 DAT and there was no statistically significant difference for the cultivar factor singly (C). There was no statistical interaction between the studied factors $(\mathrm{SL} \times \mathrm{S})$ for the evaluated periods. For 7 and 21 DAT the salinity effect was significant at $5 \%$ of probability level and for 14 DAT a statistical difference was observed at $1 \%$ of probability level by the $\mathrm{F}$ test.

A quadratic effect was observed for fresh biomass data in function of nutrient solution salinity (Figure 1). At 7 DAT a decrease occurred in the lettuce fresh biomass for treatment with $7.6 \mathrm{dS} \mathrm{m}^{-1}$ in relation to the electrical conductivity of the nutrient solution of $1.6 \mathrm{dS} \mathrm{m}^{-1}$. Similarly it occurred at 14 and 21 DAT (Figure 1), where the decreases were 28.68 and $25.05 \%$, respectively. 


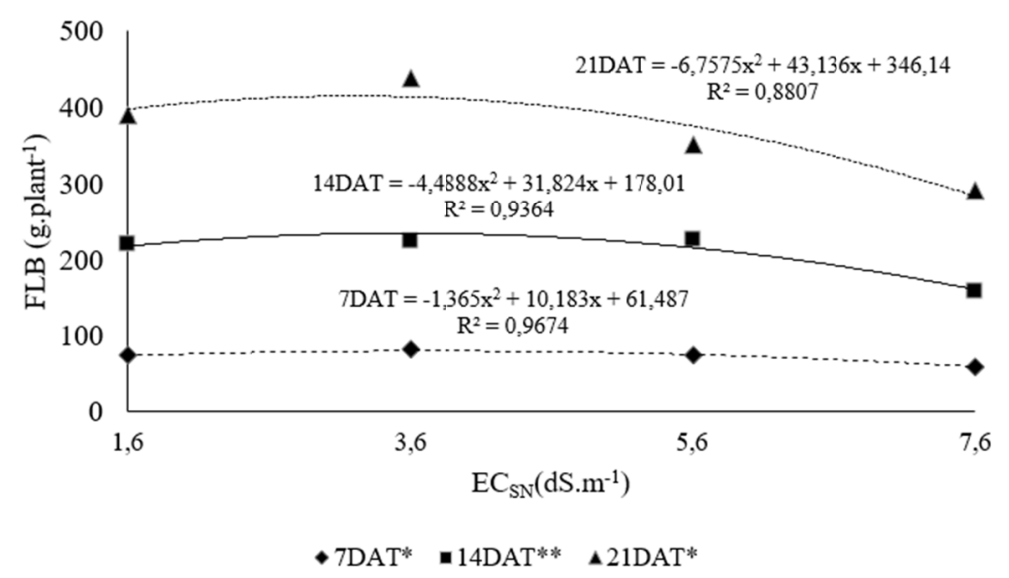

Figure 1. Fresh leaf biomass (FLB) of lettuce as function of the electrical conductivity of the nutrient solution at 7,14 and 21 DAT

It was verified that the maximum fresh biomass production ocurred at 7 DAT for the treatment with nutrient solution electrical conductivity of $3.7 \mathrm{dS} \mathrm{m}^{-1}$. At 14 and 21 DAT the highest production occurred for 3.5 and 3.2 $\mathrm{dS} \mathrm{m}{ }^{-1}$, respectively. The production during the lettuce cultivation cycle reduced considerably with the increase in electrical conductivity. This result demonstrated that exposure time to saline stress interferes in fundamental plant functions, such as photosynthesis and protein synthesis (Parida \& Das, 2005). This result demonstrated that exposure to saline stress interferes in fundamental plant functions, such as photosynthesis and protein synthesis (Parida et al., 2005). The saline stress still inhibits plants growth by osmotic effect, restricting the availability of water by toxicity and nutritional disorder besides it's induct morphological, structural and metabolic modifications (Viana et al., 2004).

The studied cultivars showed did not present a significant statistical difference. However, in absolute values, the cultivar Alcione presented the highest average in comparison to the Valentina cultivar for all levels of salinity of the solution.

The results obtained were similar to the Heidari (2012) and Bione et al. (2014), the authors observed in their research with basil under hydroponic cultivation a significant reduction of fresh biomass when using salinized nutrient solution. Rebouças et al. (2013) also reported significant influence of salinity of irrigation water on coriander fresh biomass under hydroponic cultivation, causing a decrease of this variable from 0.48 to 0.13 for electrical conductivities of 2.55 to $12.34 \mathrm{dS} \mathrm{m}^{-1}$, respectively. These results are compatible with those obtained in the present study, a fact that is possibly related to the tolerance of the culture to the salinity.

For dry leaves biomass (DLB) variable of lettuce, a significant effect $(p<0.01)$ was observed between the different saline levels (SL) only at 14 and 21 DAT. Among the cultivars, there was a significant difference $(\mathrm{p}<$ 0.01 ) only at 14 DAT such as a statistical interaction between the evaluated factors (SL $\times$ C) for the same period.

A quadratic adjustment was performed for DLB data in relation to the applied treatments and it presented a coefficient of determination of $0.99,0.64$ and 0.70 for 7, 14 and 21 DAT, respectively (Figure 2). There was a significant effect of nutritive solution at 14 and 21 DAT $(\mathrm{p}<0.01)$. 


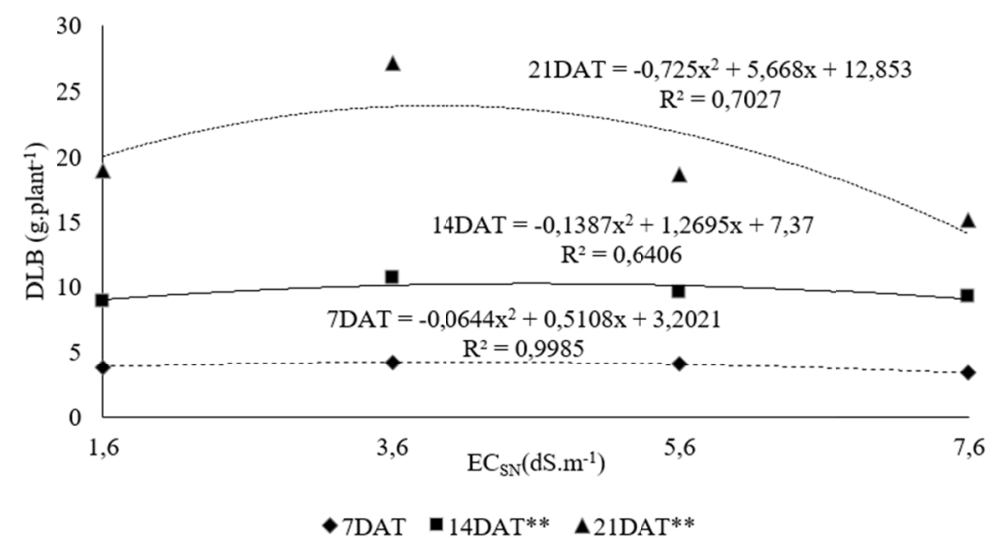

Figure 2. Dry leaves biomass (DLB) of lettuce as a function of the electrical conductivity of the nutrient solution at 7, 14 and 21 DAT

The comparison average test for DLB demonstrated a higher accumulation of biomass for Alcione (C2) cultivar under salinity of $3.6 \mathrm{dS} \mathrm{m}^{-1}$ at 14 DAT with an increase of $10.19 \%$ in relation to Valentina cultivar. Similar tendency was observed for salinity of 5.6 and $7.6 \mathrm{dS} \mathrm{m}^{-1}$ (Figure 3).

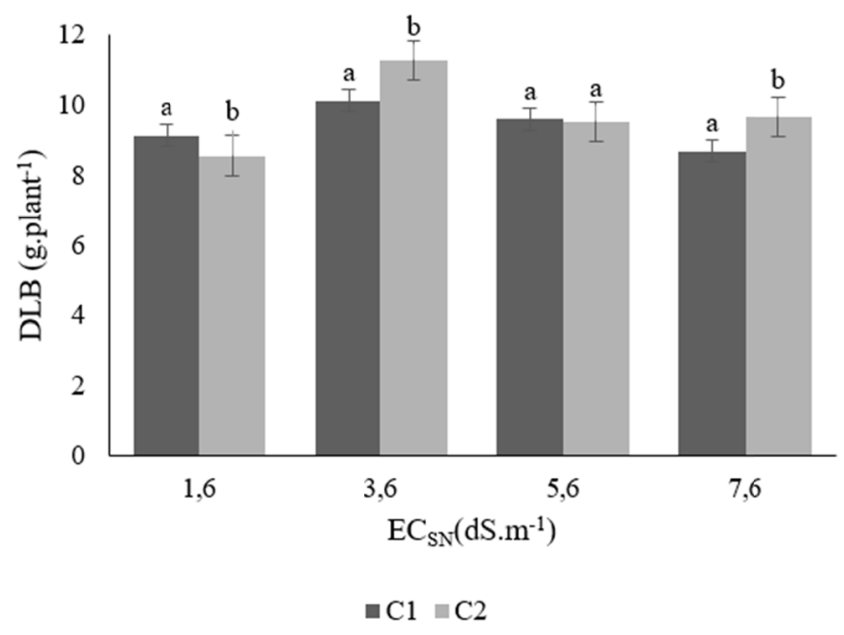

Figure 3. Comparison of dry leaves biomass (DLB) between Valentina (C1) and Alcione (C2) cultivars for the electrical conductivity of the nutrient solution at 14 DAT. Equal letters do not differ statistically from each other by the Tukey's test $(\mathrm{p}<0.05)$

According to Tester and Davenport (2003), the osmotic effect caused by salinity and ionic imbalance because of the $\mathrm{Na}^{+}$and $\mathrm{Cl}^{-}$excess causes an inadequate supply of nutrients, which may lead to a decrease in the fresh and dry biomass of some plants. This decay may still be a consequence of the osmotic potential of the salinized nutrient solution, because under these conditions the inhibition of water absorption and photosynthetic capacity of the plants occurs due to factors such as dehydration of cell membranes, salt toxicity, reduction of $\mathrm{CO}_{2}$ supply, and changes in enzymatic activities (Iyengar \& Reddy, 1996).

\subsection{Stem Biomass}

There was a significant $(\mathrm{p}<0.01)$ effect of saline (SL) levels on fresh stem biomass (FSB) at 7, 14 and 21 DAT. The cultivars $(C)$ differed statistically $(p<0.01)$ from each other only at 21 DAT. There was no statistical interaction between the factors $(\mathrm{SL} \times \mathrm{C})$ for none of the evaluated periods.

A quadratic effect was observed for FSB that presented a determination coefficient of 0.9 (Figure 4). The deleterious effects of salinity for this variable were notorious, where there was a tendency of a significant reduction in the accumulation of FSB from 7 DAT with a decrease of $38.38 \%$ when compared to S1 and S4. The 
effects of salinity increased as the exposure time of the culture to salinity increased, as shown in Figure 4, that at 14 and 21 DAT the relative decrease between S1 and S4 increased 49 and 54\%, respectively.

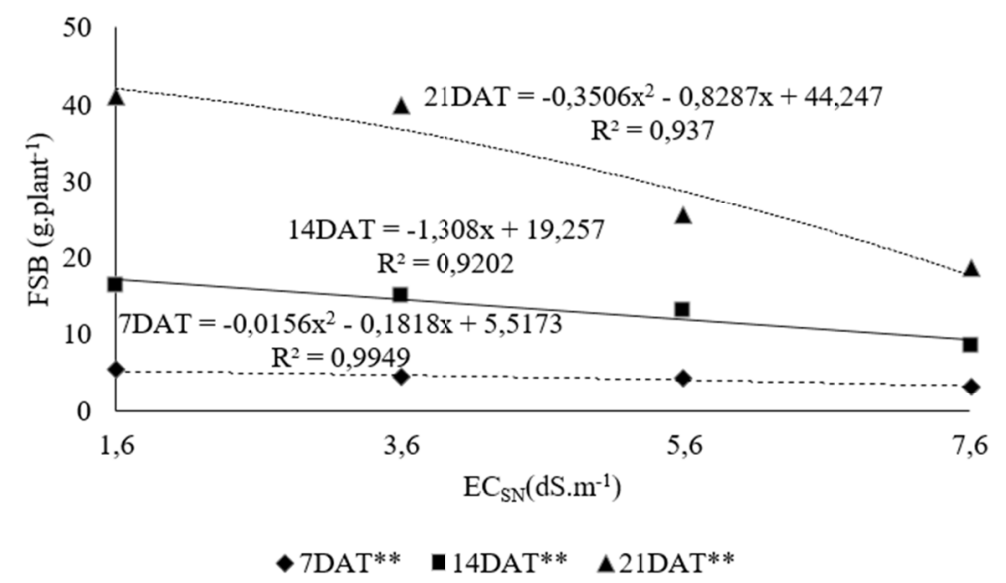

Figure 4. Fresh stem biomass (FSB) of lettuce as a function of the electrical conductivity of the nutrient solution

$$
\text { at 7, } 14 \text { and } 21 \text { DAT }
$$

In the final of the crop cycle the cultivars susceptibility for the nutrient solution was evident where a significant reduction occured on the fresh stem biomass with sality increase (Figure 5). However, it was observed that the fresh stem biomass of the cultivar Alcione (C2) presented the lowest accumulation values for all levels of salts in relation to the cultivar Valentina (C1) with decrease of 46.10, 12.42, 22.33 and $26.10 \%$ for $\mathrm{EC}_{\mathrm{SN}}$ levels 1.6, 3.6, 5.6 and $7.6 \mathrm{dS} \mathrm{m}^{-1}$, respectively. Those results indicated that prolonged conditions of salinity effect both cultivars.

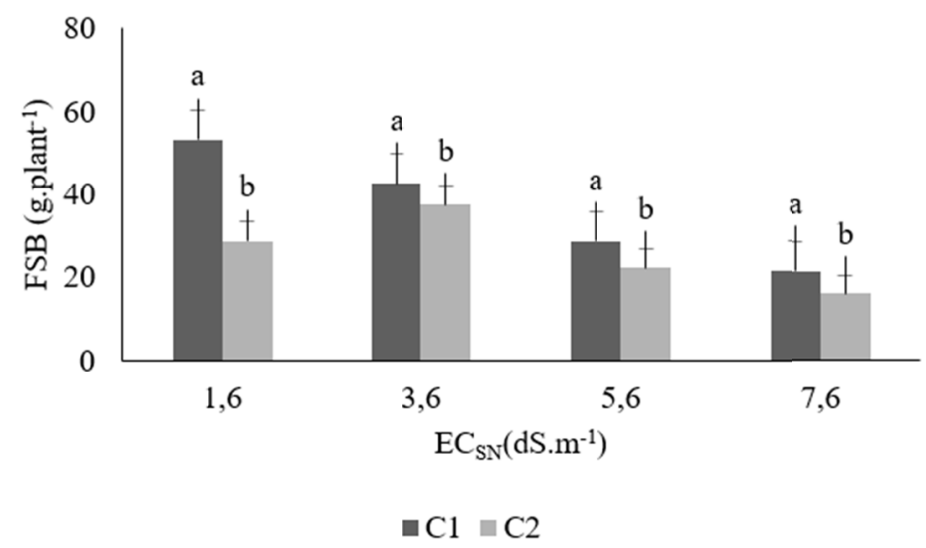

Figure 5. Comparison of fresh stem biomass (FSB) between Valentina (C1) and Alcione (C2) cultivars for the electrical conductivity of the nutrient solution at 21 DAT. Equal letters do not differ statistically from each other by the Tukey's test $(\mathrm{p}<0.05)$

The dry stem biomass (DSB) showed a significant statistical difference $(\mathrm{p}<0.01)$ between salinity levels (SL), between cultivars $(\mathrm{C})$ and statistical interaction between the factors (SL $\times \mathrm{C}$ ) only at 21 DAT. These results suggest that this variable was influenced by salinity levels of the nutrient solution as a function of time. DSB presented a quadratic effect (Figure 6). 


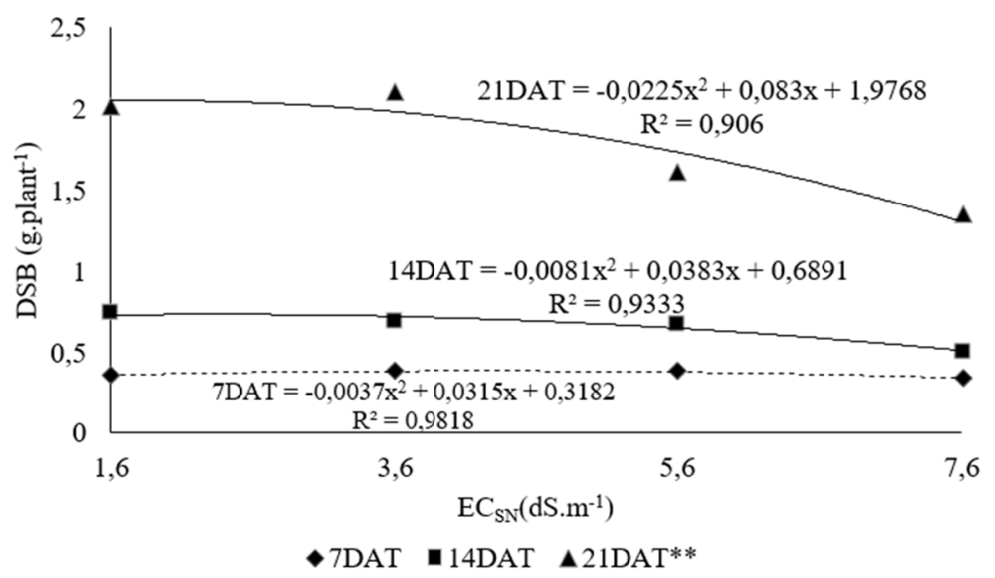

Figure 6. Dry stem biomass (DSB) of lettuce as a function of the electrical conductivity of the nutritive solution at 7,14 and 21 DAT

Rebouças et al. (2013) corroborates the results of this study, they identified a decrease in fresh stem biomass from 0.62 to $0.15 \mathrm{~g} \mathrm{plant}^{-1}$ when submitted to conductivities of 2.55 and $12.34 \mathrm{dS} \mathrm{m}^{-1}$, respectively; However, it reports that the difference was not statistically significant for the saline increment, although, according to the current study, a linear decrease of this variable was observed.

The significant decline of this variable can be justified according to Taiz and Zeiger (2009), due to the high salt concentration of the solution, which acts to disadvantage the physiological process and, consequently, to inhibit the meristematic activity and the cellular stretching of the plants.

\subsection{Biomass of Roots}

It was observed a significant statistical effect $(\mathrm{p}<0.01)$ for the lettuce fresh roots biomass (FRB) for the salinity levels only at 7 DAT. There was a significant difference $(p<0.01)$ between the cultivars for all the evaluated periods, however, no interaction effect was observed. Although there was no significant difference between the salinity levels at 14 and $21 \mathrm{DAT}$, the data were adjusted by quadratic regression equation, with determination coefficients $\mathrm{R}^{2}=0.9652$ and $\mathrm{R}^{2}=0.8594$, respectively, for fresh root biomass (Figure 7).

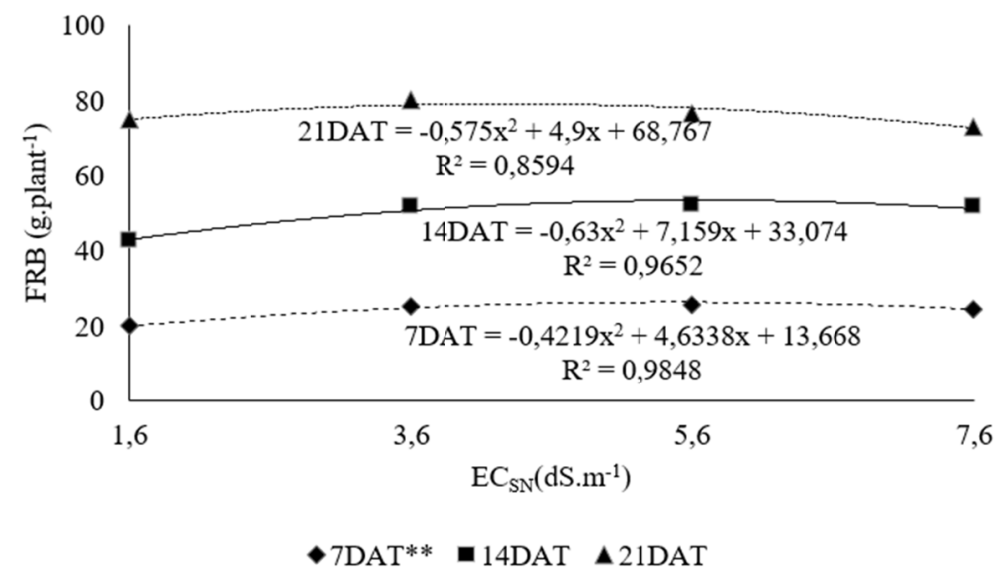

Figure 7. Fresh Root Biomass (FRB) of lettuce as a function of the electrical conductivity of the nutrient solution at 7, 14 and 21 DAT

According to Munns (1993), the growth of the root system of crops is generally less affected than the aerial part. Therefore, the difference observed at 7 DAT can be justified due to the susceptible resulting from the saline stress initially suffered by the plant; later it developed probably an osmotic adjustment mechanism that favored a greater tolerance of the roots to the salinity, which explains the non-significance of the data for the different 
levels of salts after the 14 and 21 DAT. Shalhevet et al. (1995) confirmed that the faster osmotic adjustment mechanism favors a slower turgor loss of the roots when compared to the aerial part.

Paulus et al. (2010), in a research with lettuce crop under hydroponic cultivation using saline water reported that the effect of salinity on the roots is smaller when compared to the aerial part of the lettuce in hydroponics systems; corroborating the present study, since the roots were not significantly affected by the saline increase of the nutrient solution at 14 and 21 DAT.

In addition, the cultivar Alcione (C2) presented the highest averages of fresh root biomass for all salinity levels in relation to the Valentina (C1) cultivar at 7,14 and 21 DAT. This result reflected directly in the fresh leaves biomass (FLB), where it was observed that the cultivar Alcione (C2) also presented the highest leaves biomass averages in relation to Valentina (C1). According to Soares et al. (2003), developed root system favors a higher nutrient absorption capacity and water for the plant.

Probably, the differences between cultivars occurred due to their genetic characteristics of adaptation to salt stress, which varies between crop species and between genotypes (Figueiredo et al., 2004). Yoshida (2002) pointed out that some genotypes have the ability to exclude the roots in saline medium contributing to increase ratio and express their high tolerance to salts.

Dry root biomass presented a significant statistical difference $(p<0.05)$ for the different salinity levels, only at 21 DAT. There was no difference between cultivars and no statistical interaction between the factors.

\section{Conclusions}

(1) The hydroponic production of lettuce was satisfactory in NFT system for electrical conductivity of nutritive solution up to $3.5 \mathrm{dS} \mathrm{m}^{-1}$, considering the fresh leaves biomass as the most relevant variable for commercialization of the product.

(2) The cultivar Alcione is the most tolerant to salinity of the nutrient solution.

(3) Although salinity significantly affected some analyzed variables of lettuce plants, no deleterious symptoms were identified that might compromise the commercialization of the product.

\section{References}

Alves, M. S., Soares, T. M., Silva, L. T., Fernandes, J. P., Oliveira, M. L., \& Paz, V. P. (2011). Estratégias de uso de água salobra na produção de alface em hidroponia NFT. Revista Brasileira de Engenharia Agrícola e Ambiental, 15(5), 491-498. https://doi.org/10.1590/S1415-43662011000500009

Andrade Júnior, A. S., Silva, E. F. F., Bastos, E. A., Melo, F. B., \& Leal, C. M. (2006). Uso e qualidade da água subterrânea para irrigação no Semi-Árido piauiense. Revista Brasileira de Engenharia Agrícola e Ambiental, 10(4), 873-880. https://doi.org/10.1590/S1415-43662006000400014

Andrade, T. S., Montenegro, S. M. G. L., Montenegro, A. A. A., \& Rodrigues, D. F. B. (2012). Variabilidade espaço-temporal da condutividade elétrica da água subterrânea na região semiárida de Pernambuco. Revista Brasileira de Engenharia Agricola e Ambiental, 16(5), 496-504. https://doi.org/10.1590/S1415-4366201 2000500005

Ayers, R. S., \& Westcot, D. W. (1999). A qualidade da água na agricultura (2nd ed.). Irrigação e Drenagem, 29 (p. 153). Campina Grande: UFPB.

Bione, M. A., Paz, V. D. S., Silva, F., Ribas, R. F., \& Soares, T. M. (2014). Crescimento e produção de manjericão em sistema hidropônico NFT sob salinidade. Revista Brasileira de Engenharia Agrícola e Ambiental, 18(12), 1228-1234. https://doi.org/10.1590/1807-1929/agriambi.v18n12p1228-1234

Fageria, N. K. (1989). Solos tropicais e aspectos fisiológicos das culturas (Documento, 18, p. 425). Brasília: EMBRAPA/DPU.

Ferreira, D. F. (2014). Sisvar: A Guide for its Bootstrap procedures in multiple comparisons. Ciência e Agrotecnologia, 38(2), 109-112. https://doi.org/10.1590/S1413-70542014000200001

Figueiredo, E. B., Malheiros, E. B., \& Braz, L. T. (2004). Interação genótipos $\times$ ambiente em cultivares de alface na região de Jaboticabal. Horticultura Brasileira, 22(1), 66-71. https://doi.org/10.1590/S0102-0536200 4000100013

Furlani, P. R., Silveira, L. C. P., Bolonhezi, D., \& Faquin, V. (1999). Cultivo hidropônico de plantas. Boletim Técnico, 180 (p. 52). Campinas: Instituto Agronômico. 
Heidari, M. (2012). Effects of salinity stress on growth, chlorophyll content and osmotic components of two basil (Ocimum basilicum L.) genotypes. African Journal of Biotechnology, 11(2), 379.

Iyengar, E. R. R., \& Reddy, M. P. (1996). Photosynthesis in highly salt tolerant plants. Handbook of photosynthesis. Marshal Dekar, Baten Rose, USA.

Maciel, M. P., Soares, T. M., Gheyi, H. R., Rezende, E. P., \& Oliveira, G. X. (2012). Produção de girassol ornamental com uso de águas salobras em sistema hidropônico NFT. Revista Brasileira de Engenharia Agrícola e Ambiental, 16(2), 165-172. https://doi.org/10.1590/S1415-43662012000200006

Munns, R. (1993). Physiological processes limiting plant growth in saline soils: Some dogmas and hypotheses. Plant, Cell \& Environment, 16(1), 15-24. https://doi.org/10.1111/j.1365-3040.1993.tb00840.x

Oliveira, F. D. A., Maria, J. D. O., de Medeiros, J. F., Maracajá, P. B., \& de Oliveira, M. K. (2011). Desempenho de cultivares de alface submetidas a diferentes níveis de salinidade da água de irrigação. Revista Brasileira de Engenharia Agrícola e Ambiental, 15(8), 771-778. https://doi.org/10.1590/S1415-43662011000800002

Parida, A., \& Das, A. B. (2005). Salt tolerance and salinity effects on plants: A review. Ecotoxicology and Environmental Safety, 60(3), 324-349. https://doi.org/10.1016/j.ecoenv.2004.06.010

Paulus, D., Dourado Neto, D., Frizzone, J. A., \& Soares, T. M. (2010). Produção e indicadores fisiológicos de alface sob hidroponia com água salina. Horticultura Brasileira, 28(1), 29-35. https://doi.org/10.1590/ S0102-05362010000100006

Rebouças, A. C. (1997). Água na região Nordeste: Desperdício e escassez. Estudos Avançados, 11(29). https://doi.org/10.1590/S0103-40141997000100007

Rebouças, J. R. L., Neto, M. F., Silva D. N., Souza Neto, O. N., Diniz, A. A., \& Lira, R. B. (2013). Cultivo hidropônico de coentro com uso de rejeito salino. Irriga, 18(4), 624. https://doi.org/10.15809/irriga. $2013 \mathrm{v} 18 \mathrm{n} 4 \mathrm{p} 624$

Santos, A. N., Soares, T. M., Silva, E. D. F., Silva, D. J., \& Montenegro, A. A. (2010). Cultivo hidropônico de alface com água salobra subterrânea e rejeito da dessalinização em Ibimirim, PE. Revista Brasileira de Engenharia Agrícola e Ambiental, 14(9), 961-969. https://doi.org/10.1590/S1415-43662010000900008

Shalhevet, J., Huck, M. G., \& Schroeder, B. P. (1995). Root and shoot growth responses to salinity in maize and soybean. Agronomy Journal, 87(3), 512-516. https://doi.org/10.2134/agronj1995.00021962008700030019x

Silva, E. N., Silveira, J. A. G., Rodrigues, C. R. F., Lima, C. S., \& Viégas, R. A. (2010). Contribuição de solutos orgânicos e inorgânicos no ajustamento osmótico de pinhão-manso submetido à salinidade. Pesquisa Agropecuária Brasileira, 44(5), 437-445. https://doi.org/10.1590/S0100-204X2009000500002

Soares, A. C. F., Garrido, M. S., Azevedo, R. L., Mendes, L. N., \& Grazziotti, P. H. (2003). Produção de mudas de ipê roxo inoculadas com fungos micorrízicos arbusculares. Magistra, 15(2), 123-127.

Soares, T. M. (2007). Utilização de águas salobras no cultivo da alface em sistema hidropônico NFT como alternativa agrícola condizente ao semi-árido brasileiro (Tese de Doutorado). Escola Superior de Agricultura Luiz de Queiroz, Piracicaba, Brasil.

Soares, T. M., Duarte, S. N., Silva, E. D. F., \& Jorge, C. A. (2010). Combinação de águas doce e salobra para produção de alface hidropônica. Revista Brasileira de Engenharia Agrícola e Ambiental, 14(7), 705-714. https://doi.org/10.1590/S1415-43662010000700004

Taiz, L., \& Zeiger, E. (2009). Plant physiology (Porto Alegre: Armed) (p. 719). Porto Alegre, Rio Grande do Sul, Brazil.

Tester, M., \& Davenport, R. (2003). $\mathrm{Na}^{+}$tolerance and $\mathrm{Na}^{+}$transport in higher plants. Annals of Botany, 91(5), 503-527. https://doi.org/10.1093/aob/mcg058

Viana, S. B. A., Fernandes, P. D., Gheyi, H. R., Soares, F. A. L., \& Carneiro, P. T. (2004). Índices morfofisiológicos e de produção de alfaces sob estresse salino. Revista Brasileira de Engenharia Agrícola e Ambiental, 8(1), 23-30. https://doi.org/10.1590/S1415-43662004000100004

Yoshida, K. (2002). Plant biotechnology genetic engineering to enhance plant salt tolerance. Journal of Bioscience and Bioengineering, 94(6), 585-590. https://doi.org/10.1016/S1389-1723(02)80199-2 


\section{Copyrights}

Copyright for this article is retained by the author(s), with first publication rights granted to the journal.

This is an open-access article distributed under the terms and conditions of the Creative Commons Attribution license (http://creativecommons.org/licenses/by/4.0/). 